Article

\title{
Fire Risks Associated with Combine Harvesters: Analysis of Machinery Critical Points
}

\author{
Jesús P. Val-Aguasca ${ }^{1}$, María Videgain-Marco ${ }^{1}$, Pablo Martín-Ramos ${ }^{1}{ }^{\mathbb{D}}$, Mariano Vidal-Cortés ${ }^{2}$, \\ Antonio Boné-Garasa ${ }^{3}$ and F. Javier García-Ramos ${ }^{1, * \mathbb{D}}$ \\ 1 Departamento de Ciencias Agrarias y del Medio Natural, EPS, Universidad de Zaragoza, \\ Carretera de Cuarte, s/n, 22071 Huesca, Spain; 648857@unizar.es (J.P.V.-A.); \\ mvidegain@unizar.es (M.V.-M.); pmr@unizar.es (P.M.-R.) \\ 2 Departamento de Ingeniería Mecánica, EPS, Universidad de Zaragoza, Carretera de Cuarte, s/n, \\ 22071 Huesca, Spain; vidalcor@unizar.es \\ 3 Departamento de Ingeniería de Diseño y Fabricación, EPS, Universidad de Zaragoza, Carretera de Cuarte, \\ s/n, 22071 Huesca, Spain; anbone@unizar.es \\ * Correspondence: fjavier@unizar.es; Tel.: +34-974-239-305
}

Received: 9 November 2019; Accepted: 9 December 2019; Published: 11 December 2019

\begin{abstract}
Combine harvesters are an important cause of fires worldwide. The purpose of this work has been to investigate the critical points associated with the risk of fire, identified through a survey distributed to combine owners in Aragon (Spain). Information was collected on the technical characteristics of the machines and, when appropriate, on the characteristics of the generated fires (crop, use of straw chopper, point in which the fire was originated, etc.). Based on the survey data, relationships between the characteristics of the machine and the ignition of a fire were analyzed, and the points of the harvester in which the fire originated were investigated. A statistically significant relationship of fire risk was only found with the number of hectares harvested, in such a way that the risk would be especially high for machines with more than 6000 accumulated ha. $32 \%$ of the fires were originated in the engine zone, compared with $31 \%$ in the cutting bar and $18 \%$ in the bearings and belts. The study was completed with on-site temperature measurements carried out on nine machines in 2018 and 2019, in which temperatures above $250{ }^{\circ} \mathrm{C}$ were recorded in the exhaust manifold and in the cutting bar. These temperatures exceeded the ignition thresholds obtained in the flammability studies conducted for wheat residues collected from the harvesters.
\end{abstract}

Keywords: agricultural machinery; cutting bar; EN ISO/IEC 80079-20-2; flammability; ignition temperature; straw chopper; temperature sensor

\section{Introduction}

Fires constitute a serious threat, both due to the destruction of environmental heritage and of forest crops, material goods, and human lives [1]. Taking into account the very high percentage of unwanted fires related to human activities and behaviors [2], long-term policies must focus on eliminating these causes. The analysis of social, technical, ecological, and economic factors that contribute to fire risk should be the starting point of those policies [3]. Agriculture is one of the sectors to be studied.

Agricultural losses due to fires are not limited, in the short term, to the destruction of crops, but, in the medium term, result in production capacity losses that have been estimated in $35 \%-45 \%$ in subsequent years [4].

In Spain, the causes behind fires are of a different nature. Based on monthly newsletters published by the Spanish Ministry of Agriculture, Fisheries and Food (MAPA), the causality of fires (classified into five groups: negligence and accident, intentional, natural (lightning), unknown, and fire reproduction) 
can be analyzed for the different regions. In the case of Aragon, there were 226 and 357 forest fires in 2018 and 2019, which affected a total surface of 215 and 1291 ha, respectively. The second most important cause of those fires, after negligence, was associated with agricultural machinery (including harvesters), which accounted for $8.8 \%$ of the fires that occurred in 2018 and $9.2 \%$ of those that took place in 2019.

The possible causes of fire ignition in agricultural machines and specifically in harvesters are very varied. Quick [5] lists a number of potential points in which fire can start: engine and flue gas outlets, transmissions, bearings, brakes, electrical short-circuits, impact of mowing heads with stones or other elements, and introduction of foreign bodies into the machine. Of all of them, the most common cause is the accumulation of combustible material in points with high temperatures located near the engine. The surface temperatures of these elements can reach $500{ }^{\circ} \mathrm{C}$ [5], exceeding the ignition temperatures of the crop residues, which vary depending on the thickness of the sample, but which are generally above $200^{\circ} \mathrm{C}$ in the case of wheat straw [6]. As for the spread of the fire, field conditions can favor or hinder the process, which would be influenced by four main factors: relative humidity, ambient temperature, wind speed, type and condition of the crop $[5,7]$.

Despite the importance of the consequences of agricultural and forest fires, there are hardly any studies focused on the causes of fires in combine harvesters. So far, the most important studies have been those carried out in the USA by Shutske et al. [8,9], in which the authors investigated over 4000 fires in harvesters and tractors, and were able to gain access to the machine to perform a detailed study in 265 cases. Based on the data obtained, the authors concluded that $74 \%$ of the fires originated in the engine area due to different causes (e.g., surface heating, combustion gas outlet, and electrical components). It was also concluded that the material that started the fire was generally the crop residues, followed by fuel and oil remains.

In Australia, another study by White et al. [10] (Kondinin group), conducted with data from 1170 farmers, reported that approximately $25 \%$ of respondents had experienced a fire in their harvesters. According to the farmers, the main cause of fire was the accumulation of dust and crop residues on the hot surfaces of the machine (33\% of the cases) followed by the heating of bearings $(22 \%)$. It was also concluded that regular maintenance and cleaning of the machine was key to reducing the risk of fire. In another study, also carried out in Australia, Quick [5] analyzed 77 cases of fires in harvesters, estimating that $45 \%$ of the fires originated in the area of the engine, followed by bearings and transmissions with $22 \%$. It was also concluded that the accumulation of electrostatic charges was an important cause for the ignition of the fire, highlighting the importance of an appropriate maintenance and monitoring of the equipment to prevent fires. In Turkey, Keskin et al. [11] examined 116 combine harvesters field accidents, concluding that $41.4 \%$ of those accidents were caused by fire originated in engine, fuel loading, cutting head, and electric contacts.

In the absence of data in Spain, this work aims to provide information on the risks of fire in harvesters in Aragon, in order to characterize the profile of the machines that would be more prone to start a fire. To this end, a survey was distributed among harvester owners and several machines were continuously monitored throughout the 2018 and 2019 summer harvest campaigns in order to obtain information about the temperatures reached in different parts of the machines, comparing them with flammability studies for wheat residues collected from the harvesters.

\section{Material and Methods}

\subsection{Survey}

A survey was carried out among harvester owners in Aragon with a view to identifying critical points of the machinery, as well as to characterize the profile of the machines with the highest risk of fire. The survey was structured in two blocks: the first one referred to the technical characteristics of the machine (manufacturer, power, age of the machine, harvested hectares, etc.) and was applicable to all harvesters, while the second block focused on the characteristics of the fire in the harvester (crop, 
point of the machine in which the fire originated, etc.) and only applied to harvesters associated with fires. The complete survey is available at http://bit.ly/encuestacosechadoras.

Subsequently, a statistical analysis was performed with SPSS v.18 software (IBM, Chicago, IL, USA). The analysis had three parts: first, the relationship between the power, age, and annual harvested hectares variables was analyzed, creating a new variable named "accumulated hectares", which represented the number of hectares that had been harvested when the fire occurred (that is, annual harvested hectares $x$ age) and which would refer to the wear or use of the machine at the time of the fire. In a second stage, the relationship of the variables mentioned above with the risk of fire was studied, using contingency tables. For this, categorical variables were created for the accumulated hectares $(0-2000,2001-4000,4001-6000$, and $>6000$ ha) and for the age of the machine $(0-10,11-20$, and $>20$ years). In the third part, the areas of origin of the fire were investigated.

\subsection{Flammability and Susceptibility to Spontaneous Combustion Studies}

In the 2018 harvest season, samples of wheat residue accumulated in different areas of five combine harvesters (cutting head, front axle, straw chopper, engine area, lateral area of the machine with transmissions to cleaning systems) were collected in order to study their ignition point properties, correlating them with the temperatures measured in the harvesters. The proximate and elemental analysis results are summarized in Table S1, and the granulometric analysis results are reported in Table S2.

Wheat residues were dried in an oven at $105^{\circ} \mathrm{C}$ for $24 \mathrm{~h}$. Subsequently, samples were sieved using a sieve tower with five sieves (with 4,2,1 mm, 500 and $250 \mu \mathrm{m}$ mesh apertures) and a BA200N electromagnetic sieve shaker (CISA, Barcelona, Spain), for $3 \mathrm{~min}$ and with an oscillation amplitude of $2 \mathrm{~mm}$.

The combustion mechanism was investigated by thermogravimetric/derivative thermogravimetric (TG/DTG) and differential scanning calorimetry (DSC) analyses, conducted using a TG-DSC2 (Mettler-Toledo, Columbus, OH, USA) simultaneous analyzer. The analyses were carried out both in inert $\left(\mathrm{N}_{2}\right)$ and oxidizing (air) atmosphere, in the $25-600{ }^{\circ} \mathrm{C}$ range, at a heating rate of $20^{\circ} \mathrm{C} / \mathrm{min}$.

Ignition tests were carried out according to UNE-EN ISO/IEC 80079-20-2:2016. “Explosive atmospheres. Part 20-2: Material characteristics-Combustible dusts test methods". Three thicknesses of wheat residue $(5,10$, and $15 \mathrm{~mm})$ were assayed, and for each thickness three particle sizes $(<250,250$, and $500 \mu \mathrm{m}$ ) were tested. A fully compliant custom-made hot plate layer ignition apparatus, supplied by the Electronic Instrumentation Laboratory at Universidad de Zaragoza, was used in the tests.

\subsection{In Situ Harvester Monitoring}

Throughout the 2018 and 2019 harvest campaigns, nine machines were monitored, installing temperature probes (type $\mathrm{K}$ thermocouples) in different points of each machine, in addition to ambient temperature/humidity probes (HOBO Pro v2; Onset Computer Corp., Bourne, MA, USA) outside (in the exterior antennas of the cabins). The points selected to place the temperature probes were chosen based on the risk zones detected in the initial survey and on the feasibility of placing temperature probes during the harvest process (Table 1): exhaust manifold, selective catalytic reduction system (SCR, next to the urea injection point), diesel particulate filter (DPF), engine block, gearbox, engine transmission output, hydrostatic system output, and engine cylinder heads. Table 2 shows the main characteristics of the monitored harvesters, which were selected with the aim of having a variety of machines that could be sufficiently representative of the fleet of harvesters in Aragón. 
Table 1. Probe locations in the monitored harvesters.

\begin{tabular}{cccccccc}
\hline \multirow{2}{*}{ Probe Location } & \multicolumn{7}{c}{ Harvester } \\
\cline { 2 - 7 } & $\mathbf{1}$ & $\mathbf{2}$ & $\mathbf{3}$ & $\mathbf{4}$ & $\mathbf{5}$ & $\mathbf{6 - 7 - 8 - 9}$ \\
\hline Exhaust manifold & $\mathrm{X}$ & & $\mathrm{X}$ & $\mathrm{X}$ & $\mathrm{X}$ & $\mathrm{X}$ \\
SCR * & $\mathrm{X}$ & & & & & \\
DPF * & & $\mathrm{X}$ & & & & \\
Engine block & & $\mathrm{X}$ & $\mathrm{X}$ & $\mathrm{X}$ & $\mathrm{X}$ & $\mathrm{X}$ \\
Gearbox & $\mathrm{X}$ & $\mathrm{X}$ & & & & \\
Engine transmission output & $\mathrm{X}$ & $\mathrm{X}$ & $\mathrm{X}$ & $\mathrm{X}$ & & $\mathrm{X}$ \\
Hydrostatic system output & & & & $\mathrm{X}$ & $\mathrm{X}$ & \\
Engine cylinder heads & & & & & $\mathrm{X}$ & \\
SCR and DPF stand for selective catalytic reduction and diesel particulate filter, respectively.
\end{tabular}

Table 2. Characteristics of the combine harvesters monitored in 2018 and 2019.

\begin{tabular}{ccccccc}
\hline Machine & $\begin{array}{c}\text { Power } \\
\mathbf{( H P / k W )}\end{array}$ & $\begin{array}{c}\text { Age } \\
\text { (years) }\end{array}$ & $\begin{array}{c}\text { Cutting } \\
\text { Width } \mathbf{( m )}\end{array}$ & ha/year & $\begin{array}{c}\text { Technical } \\
\text { Characteristics }\end{array}$ & $\begin{array}{c}\text { Monitored Period } \\
\mathbf{( d d} / \mathbf{m m} / \mathbf{y y})\end{array}$ \\
\hline Machine \#1 & $435 / 320$ & 0 & 7.7 & $>500$ & SCR + EGR (w/o filter) & $15 / 06 / 18-16 / 07 / 18$ \\
Machine \#2 & $435 / 320$ & 2 & 7.7 & $>500$ & EGR + DPF & $15 / 06 / 18-16 / 17 / 18$ \\
Machine \#3 & $160 / 119$ & 16 & 5.1 & 200 & Untreated exhaust & $15 / 06 / 18-16 / 07 / 18$ \\
Machine \#4 & $250 / 184$ & 8 & 6.1 & $>500$ & Untreated exhaust & $18 / 06 / 19-01 / 07 / 19$ \\
Machine \#5 & $180 / 132$ & 16 & 5.2 & $>500$ & Untreated exhaust & $18 / 06 / 19-01 / 07 / 19$ \\
Machine \#6 & $275 / 202$ & 3 & 6.7 & $>500$ & EGR + DPF & $13 / 06 / 19-06 / 07 / 19$ \\
Machine \#7 & $220 / 164$ & 10 & 6.0 & 350 & EGR (w/o filter) & $22 / 06 / 19-04 / 07 / 19$ \\
Machine \#8 & $400 / 294$ & 0 & 7.0 & $>500$ & SCR + EGR + DPF & $03 / 07 / 19-19 / 07 / 19$ \\
Machine \#9 & $420 / 309$ & 13 & 7.0 & $>500$ & Untreated exhaust & $04 / 07 / 19-19 / 07 / 19$ \\
\hline
\end{tabular}

* SCR, EGR, and DPF stand for selective catalytic reduction, exhaust gas recirculation, and diesel particulate filter, respectively.

Additionally, a test was carried out with a harvester's cutting bar in poor conditions and with very little maintenance, with the cutting bar running and the machine parked. For this, three thermocouples were installed in the cutting bar (on a blade with friction, on a normal blade, and on a cutting plate) to monitor temperature evolution. One of the probes installed on the cutting bar is shown in Figure 1.

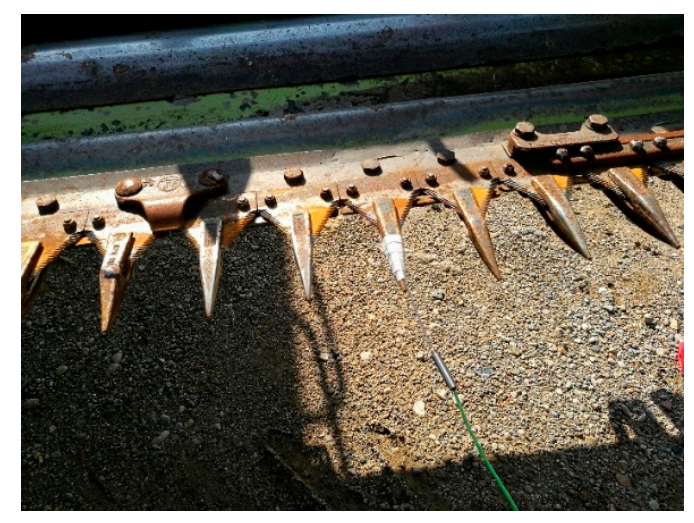

Figure 1. Temperature probe installed in the cutting bar.

Aforementioned direct temperature measurements were complemented with those obtained with a Ti200 infrared thermal camera (Fluke Corp., Everett, WA, USA). This real-time non-contact condition monitoring tool is useful for early detection of equipment flaws [12] and, in the particular case of grain harvesters, has been successfully used to monitor the temperature in belt transmissions [13]. 


\section{Results and Discussion}

\subsection{Relationships between Variables}

In the survey distributed among combine harvester owners, data from 221 harvesters were obtained, reporting 74 cases of fire. Based on the data of the 221 harvesters, Figure 2 shows the relationships between the harvested hectares per year, power, age, and accumulated hectares variables, starting from the hypothesis that the machines that harvest more hectares per year will be more exposed and may be more likely to cause a fire. It can be observed that the machines that harvest more hectares per year have higher power levels, are newer, and have a higher number of accumulated harvested hectares (i.e., greater wear).
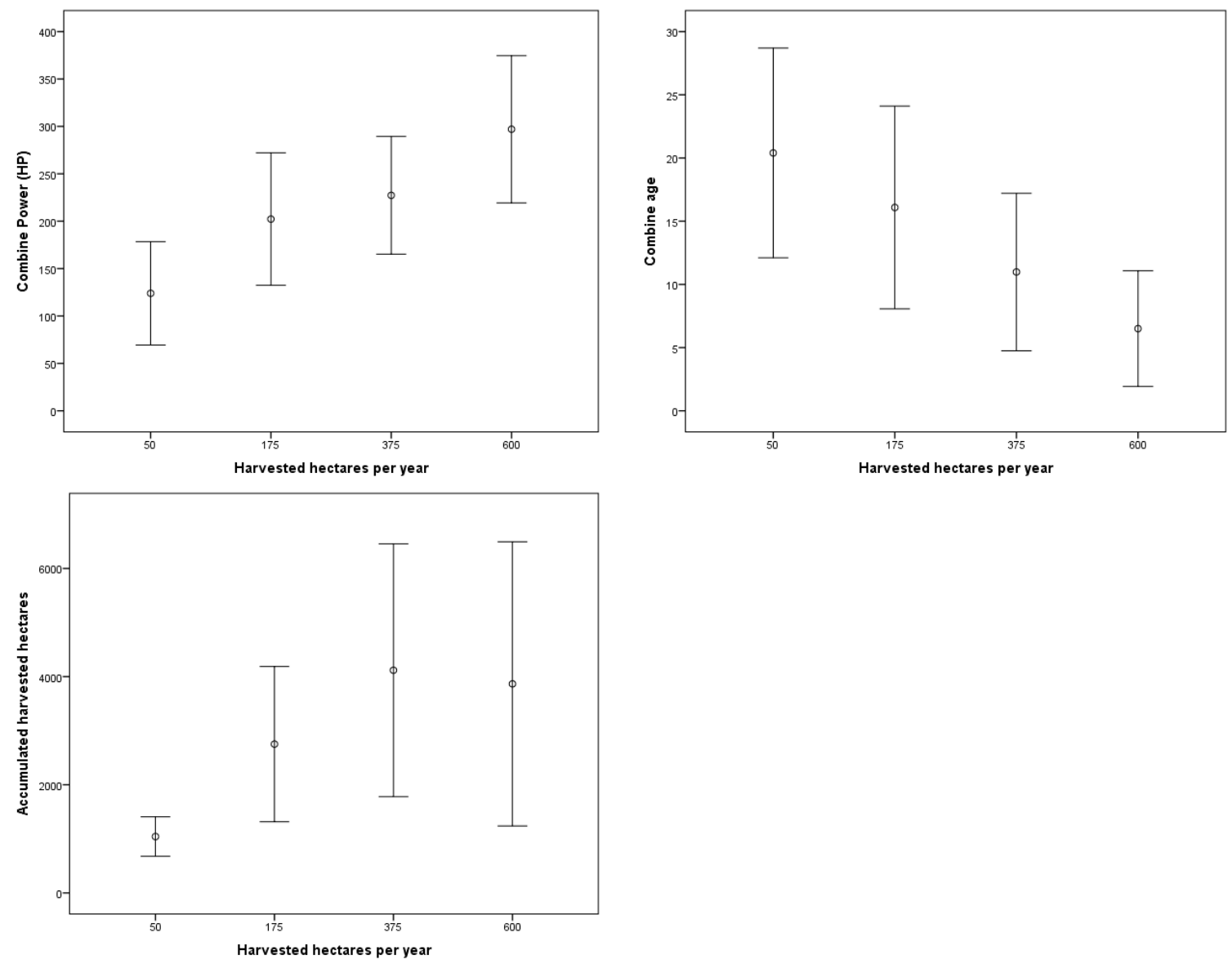

Figure 2. Relationship between the annual hectares, power, age, and accumulated hectares variables considering the 221 harvesters included in the survey. Mean values \pm standard deviations are shown.

\subsection{Relationship between Variables and Fire}

From the contingency tables of each variable with respect to fire, it was observed that the age $\left(\chi^{2}=0.673\right)$, power $\left(\chi^{2}=0.723\right)$, and annual hectares $\left(\chi^{2}=0.766\right)$ variables did not show a statistically significant relationship with fire. However, for the accumulated hectares variable a $\chi^{2}=0.055$ was obtained, very close to the level of significance (0.05). The contingency table showed very similar fire percentages for machines that had worked up to $6000 \mathrm{ha}$, but, once this threshold had been exceeded, the fire percentage would be high $(60 \%)$.

Since the total accumulated hectares was the only variable that was related to fire risk, a more detailed analysis of possible relationships of this variable with the rest of the variables was carried out. No significant relationship was detected with the use of the straw chopper $\left(\chi^{2}=0.282\right)$, but a significant 
relationship was observed with the power variable $\left(\chi^{2}=0.012\right)$, apart from the age $\left(\chi^{2}=0.000\right)$, and annual hectares $\left(x^{2}=0.000\right)$ variables of which it directly depended.

The relationships between the three variables, considering only the 74 harvesters for which fire cases were reported, are shown in Figure 3. The profile of machines with more than 6000 accumulated ha and that would present a greater probability of fire would correspond to machines with an average power of $286 \mathrm{HP}$, an average age of 15 years and which harvest an average of 548 ha/year. Currently this machine profile represents $11 \%$ of the total harvesters in Spain.
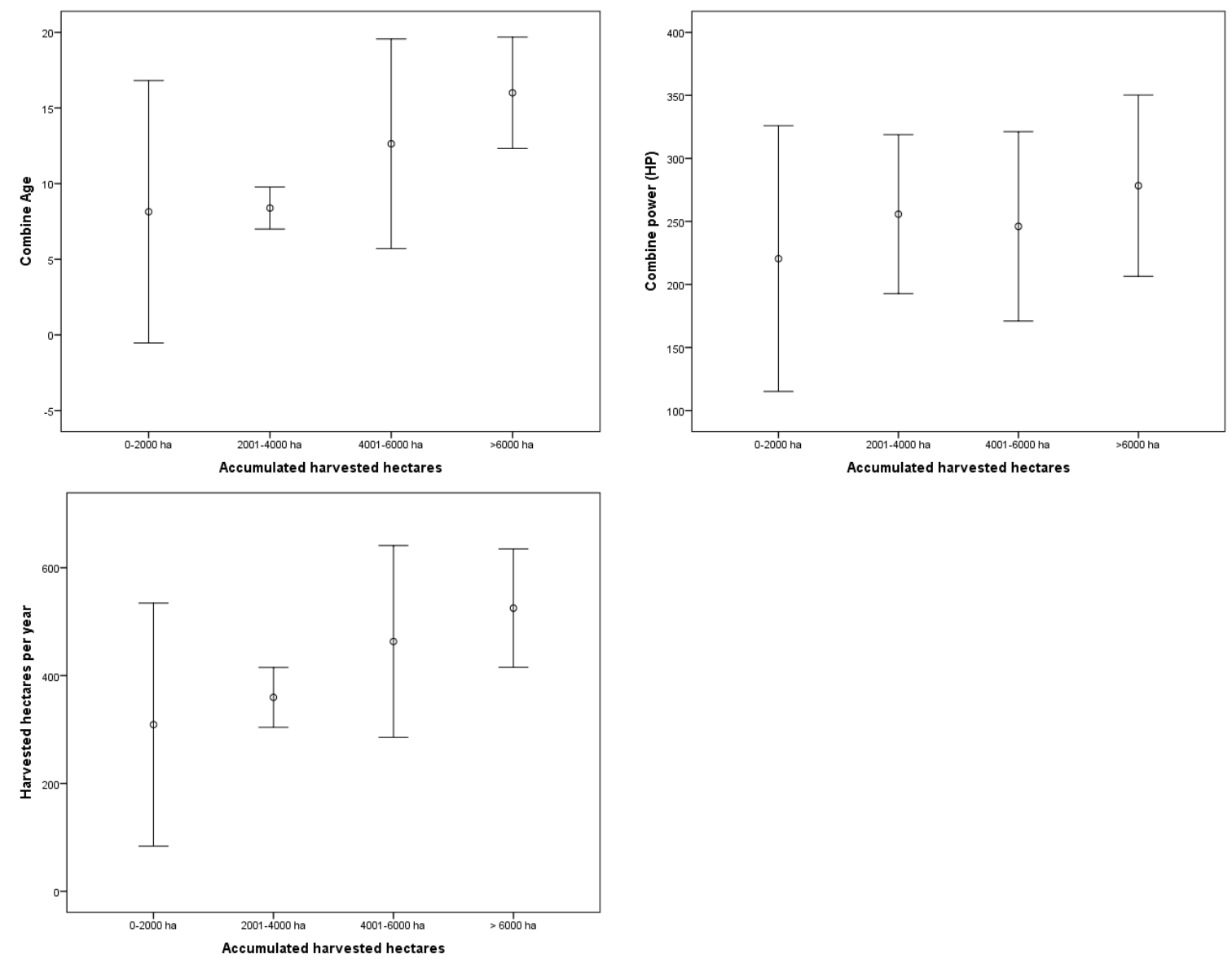

Figure 3. Relationship between the accumulated hectares and annual hectares, power, and age considering only the 74 harvesters associated with fire cases. Average values \pm standard deviations are shown.

Information on the relationship between combine characteristics and fire is very limited and controversial. Shutske et al. [8], considering 50 combine fires, described a mean harvester age of 8.1 years and an average accumulated machine use at the time of the fire of $1640 \mathrm{~h}$. This research was carried out in 1988, when a typical working width was $6 \mathrm{~m}$. In this sense, for an average forward speed of $4 \mathrm{~km} / \mathrm{h}$, the number of accumulated hectares in $1640 \mathrm{~h}$ would be $3936 \mathrm{ha}$. These values (age and accumulated hectares) are significantly lower than those obtained in the current research for the machine profile with higher fire risk. On the other hand, White et al. [10] did not find a relationship between the average hours accumulated by the machine and fire occurrence in the case of 396 combines of several models of five different brands, with an accumulated hours range that varied from 393 to $2189 \mathrm{~h}$. 


\subsection{Determination of Fire Source Areas}

Based on the contingency table in which the relationship between the area of origin of the fire and the use of the straw chopper was analyzed, a value of $\chi^{2}=0.159$ was obtained, so the use of the straw chopper did not favor the origin of the fire in any specific area of the machine.

In Table 3, the fire source areas are shown according to the data collected in the survey and from data provided by an insurance company (updated in 2017). In both cases, it could be observed that the area in which more fires originated was the engine $(\sim 32 \%)$. However, according to the insurer's data, the second most important cause of fire would be electric failures $(26 \%)$, while in the survey this cause was estimated to account for $10 \%$ of the fires. According to the data collected in the survey, the second area in which more fires would originate would be the cutting bar (31\%), which only accounted for $11 \%$ of the fires according to the insurer. Bearings, belts, and other areas of the machine (brakes, alternator, straw chopper, etc.) presented similar percentages in the survey and in the insurer's database. If these data are compared with the literature [5,8-10], the results are coincident in that the engine area would be the main cause of fire, and in that the bearings and belts would also be responsible for a significant percentage of the fires.

Table 3. Comparison of main areas of origin of fire in harvesters.

\begin{tabular}{cccccc}
\hline Zone & Survey & Insurance Company & Quick [5] & Shutske et al. [8] & Shutske et al. [9] \\
\hline Cutting bar & $30.77 \%$ & $11.11 \%$ & $6.49 \%$ & - & $3 \%$ \\
Electrical causes & $8.79 \%$ & $25.93 \%$ & $12.99 \%$ & $34 \%$ & $14 \%$ \\
Engine & $31.87 \%$ & $33.33 \%$ & $45.45 \%$ & $40 \%$ & $33 \%$ \\
Other areas & $10.99 \%$ & $7.41 \%$ & $12.97 \%$ & $8 \%$ & $28 \%$ \\
Bearings and belts & $17.58 \%$ & $22.22 \%$ & $22.10 \%$ & $18 \%$ & $22 \%$ \\
\hline
\end{tabular}

\subsection{Thermal Analysis, Hot Plate Auto-Ignition Point of the Residues}

Figure S1 shows the TG, DTG, and DSC curves related to the wheat residue samples, in an inert atmosphere and in an oxidative atmosphere. In the TG curve, several stages of weight loss could be observed. The first stage, between room temperature and $150{ }^{\circ} \mathrm{C}$, would be related to moisture removal. In the second stage $\left(150-350{ }^{\circ} \mathrm{C}\right)$, depending on the atmosphere, up to $50 \%$ of the mass would be volatilized, and would correspond to oxidative pyrolysis and release of volatiles coming from the thermal decomposition of hemicellulose, cellulose, and part of lignin. True combustion would take place above $350^{\circ} \mathrm{C}$, in which lignin residues and a mixture of carbonaceous solids (with a small mineral component) would undergo moderate combustion (smoldering) up to approximately $500{ }^{\circ} \mathrm{C}$. At temperatures of $600{ }^{\circ} \mathrm{C}$, weight losses of over $60 \%$ in $\mathrm{N}_{2}$ atmosphere and of ca. $80 \%$ in $\mathrm{O}_{2}$ atmosphere were registered. The weight loss maxima were sensitized on DTG curves with peaks at $72-72.8,300-307$, and $456{ }^{\circ} \mathrm{C}$, depending on operative conditions.

The DSC curve in $\mathrm{O}_{2}$ atmosphere was characterized by the presence of two endotherms between 300 and $500{ }^{\circ} \mathrm{C}$, corresponding to the hemicellulose and cellulose decomposition reactions, with maxima at 324 and $458^{\circ} \mathrm{C}$. The former corresponds to oxidative pyrolysis and the latter to combustion.

From the thermal analysis data, it could be inferred that the lowest temperature at which ignition could occur was $150^{\circ} \mathrm{C}$, and that a perfectly declared process would occur at $307^{\circ} \mathrm{C}$, with an associated heat of reaction close to $900 \mathrm{~kJ} / \mathrm{kg}$.

The results of the hot-plate auto-ignition tests are shown in Table 4. A decrease in ignition temperature was observed when the particle size of the residue was smaller, in agreement with the findings of Polin et al. [14] for sunflower dust field samples from combine harvesters. Similarly, for the same particle size, the ignition temperature decreased as the sample thickness increased. The minimum ignition temperature was $250{ }^{\circ} \mathrm{C}$, associated with the $250 \mu \mathrm{m}$ residue and a thickness of $15 \mathrm{~mm}$. These results were in good agreement with those obtained by Fernandez-Anez et al. [6], who reported a value of $250{ }^{\circ} \mathrm{C}$ for a thickness of residue of $50 \mathrm{~mm}$. 
It must be taken into consideration that in combine harvesters the residue particles show a size distribution in which small sizes constitute a high percentage in weight. Polin et al. [15], working with sunflower residue, obtained a $78 \%$ of residue particles below $750 \mu \mathrm{m}$. In the study presented herein, $66 \%$ of the residue particles collected from the five combine harvesters were below $1 \mathrm{~mm}$.

An univariate test of between-subjects effects was conducted for temperatures as a function of the exhaust gases treatment system considering the five technologies present in the machines tested (Table 2: EGR+DPF, EGR, SCR+EGR+DPF, SCR+EGR, and untreated exhaust; where EGR, DPF and SCR stand for exhaust gas recirculation, diesel particulate filter and selective catalytic reduction, respectively). According to Table S3, there were significant temperature differences $(F=1550.14$; $p=0.000$ ) depending on the exhaust gases treatment system. Results of Tukey's HSD test showed differences between all systems, with the highest mean temperatures in SCR+EGR and SCR+EGR+DPF systems (Table 5 and Figure S2). These results are in good agreement with the findings reported by Quick [5], who referred that higher temperatures in combine harvesters adapted to Tier 3 (particulate matter restrictions) and Tier 4 (particulate matter and $\mathrm{NO}_{\mathrm{x}}$ restrictions) emission control standards for engines.

Table 4. Results of hot-plate auto-ignition tests of wheat residue layers according to UNE-EN ISO/IEC 80079-20-2:2016.

\begin{tabular}{|c|c|c|c|c|}
\hline Thickness & Size & Surface Temperature $\left({ }^{\circ} \mathrm{C}\right)$ & Test Result & Ignition Time (min) \\
\hline \multirow{9}{*}{$5 \mathrm{~mm}$} & \multirow{3}{*}{$<250 \mu \mathrm{m}$} & 290 & Ignition & 5 \\
\hline & & 280 & No Ignition & 30 \\
\hline & & 280 & No Ignition & 30 \\
\hline & \multirow{2}{*}{$250 \mu \mathrm{m}$} & 320 & Ignition & 3 \\
\hline & & 310 & No Ignition & 30 \\
\hline & \multirow{2}{*}{$500 \mu \mathrm{m}$} & 340 & Ignition & 3 \\
\hline & & 330 & No Ignition & 30 \\
\hline & \multirow{2}{*}{$1 \mathrm{~mm}$} & 360 & Ignition & 2 \\
\hline & & 350 & No Ignition & 30 \\
\hline \multirow{10}{*}{$10 \mathrm{~mm}$} & \multirow{3}{*}{$<250 \mu \mathrm{m}$} & 280 & Ignition & 7 \\
\hline & & 270 & Ignition & 10 \\
\hline & & 260 & No Ignition & 45 \\
\hline & \multirow{3}{*}{$250 \mu \mathrm{m}$} & 300 & Ignition & 5 \\
\hline & & 290 & Ignition & 6 \\
\hline & & 280 & No Ignition & 45 \\
\hline & \multirow{4}{*}{$500 \mu \mathrm{m}$} & 320 & Ignition & 3 \\
\hline & & 310 & Ignition & 5 \\
\hline & & 300 & Ignition & 6 \\
\hline & & 290 & No Ignition & 45 \\
\hline \multirow{12}{*}{$15 \mathrm{~mm}$} & \multirow{3}{*}{$<250 \mu \mathrm{m}$} & 260 & Ignition & 13 \\
\hline & & 250 & Ignition & 28 \\
\hline & & 240 & No Ignition & 120 \\
\hline & \multirow{4}{*}{$250 \mu \mathrm{m}$} & 280 & Ignition & 11 \\
\hline & & 270 & Ignition & 12 \\
\hline & & 260 & Ignition & 17 \\
\hline & & 250 & No Ignition & 60 \\
\hline & \multirow{5}{*}{$500 \mu \mathrm{m}$} & 290 & Ignition & 10 \\
\hline & & 280 & Ignition & 12 \\
\hline & & 270 & Ignition & 16 \\
\hline & & 260 & Ignition & 20 \\
\hline & & 250 & No Ignition & 90 \\
\hline
\end{tabular}


Table 5. Results from Tukey's HSD (honestly significant difference) test for temperatures as a function of the exhaust gases treatment system.

\begin{tabular}{ccccccc}
\hline & & \multicolumn{5}{c}{ Subset } \\
\cline { 3 - 6 } Exhaust Gases Treatment System & $\mathbf{N}$ & $\mathbf{1}$ & $\mathbf{2}$ & $\mathbf{3}$ & $\mathbf{4}$ & $\mathbf{5}$ \\
\hline EGR + DPF & 1665 & 82.5238 & & & & \\
EGR (w/o filter) & 1036 & & 110.6356 & & & \\
Untreated exhaust & 3626 & & & 147.5165 & & 163.3424 \\
SCR + EGR + DPF & 773 & & & & & 190.2254 \\
SCR + EGR (w/o filter) & 2448 & & & & 1.000 & 1.000 \\
Sig. & & 1.000 & 1.000 & 1.000 & 1.000 \\
\hline
\end{tabular}

Means for groups in homogeneous subsets are displayed. Based on observed means. The error term is mean square error $=2098.044$. Tukey's HSD test uses harmonic mean sample size $=1410.917$. The group sizes are unequal. The harmonic mean of the group sizes is used. Type I error levels are not guaranteed. Alpha $=0.05$.

\subsection{On-Site Monitoring of Harvesters}

Temperature data collected in the nine machines monitored in field conditions is summarized in Table 6. It is worth noting that the highest temperatures were recorded in the exhaust manifold for all machines, with maximum temperatures above $200^{\circ} \mathrm{C}$ in five of the machines and, in two cases (machines \#1 and \#4), with temperatures above $250{ }^{\circ} \mathrm{C}$, which reached up to $305^{\circ} \mathrm{C}$ in machine \#1, showing an important risk of residue ignition. This would corroborate that the engine zone (exhaust manifold) would be a key zone, in which temperatures above the ignition temperature of the crop residue $[5,6]$ can be reached.

It is important to keep in mind that the risk of fires originated in harvesting machines increases when the weather conditions are adverse [8]. Venem et al. [16] concluded that $48.5 \%$ of the fires coincided with the hours of highest temperatures (2:00-4:00 pm). In Table 6 it may be observed that ambient temperatures reached extreme values coinciding with temperatures higher than $250{ }^{\circ} \mathrm{C}$ in the exhaust manifold of some machines, thus constituting high fire risk situations. Given that the annual number of high-temperature days (HTDs, viz. days with mean temperatures higher than 20, 22.5, and $25^{\circ} \mathrm{C}$ ) is increasing across southern Europe, as shown by Cardil et al. [17] for temperature data in the June-September period from 1978 to 2012 in the south of France, interior Spain, and the northwestern Iberian Peninsula, the probability of such high fire risk situations is expected to continue increasing.

Considering an ignition temperature of the wheat residue of ca. $250{ }^{\circ} \mathrm{C}$, machines \#1 and \#4 were analyzed in more detail, in order to determine the operating time in which this threshold was exceeded (in this case in the exhaust manifold). Figure 4 shows the temperatures registered during the test period in the exhaust manifold of machines \#1 and \#4.
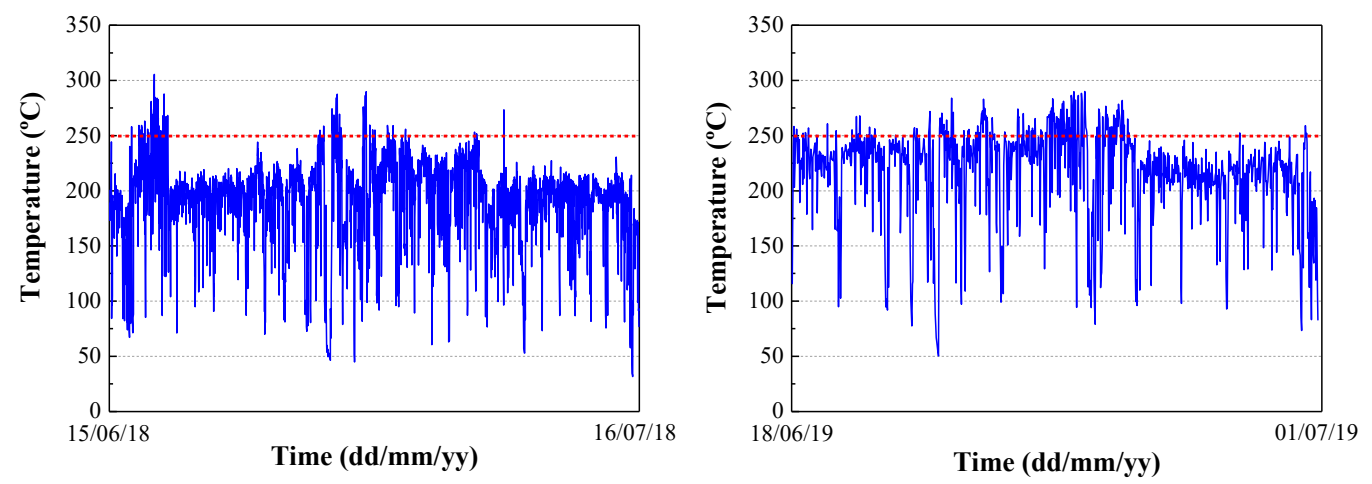

Figure 4. Temperature evolution in the exhaust manifold (blue) versus straw ignition temperature (red). Left: Machine \#1; Right: Machine \#4. Periods in which the machines were not working (e.g., nights) are not shown. 
In the case of machine \#1, one can observe that this threshold $\left(250^{\circ} \mathrm{C}\right)$ was occasionally exceeded (specifically, $3.51 \%$ of the working time), while in machine \#4 the threshold was exceeded during a $16.63 \%$ of the working time, thus generating a high risk of ignition of the residue and, consequently, of fire.

Table 6. Temperatures recorded during the 2018 and 2019 campaigns in the nine harvesters monitored in field conditions. Maximum ambient temperatures and the associated relative humidity $(\mathrm{RH})$ are also shown for comparison purposes.

\begin{tabular}{|c|c|c|c|c|c|c|}
\hline \multirow{2}{*}{ Machine } & \multirow{2}{*}{ Probe Location } & \multirow{2}{*}{$N$} & \multicolumn{2}{|c|}{ Combine Harvester } & \multicolumn{2}{|c|}{ Ambient Conditions } \\
\hline & & & $\mathrm{T}_{\mathrm{op}}\left({ }^{\circ} \mathrm{C}\right)$ & $\mathrm{T}_{\max }\left({ }^{\circ} \mathrm{C}\right)$ & $\mathrm{T}_{\max }\left({ }^{\circ} \mathrm{C}\right)$ & RH (\%) \\
\hline \multirow{4}{*}{ Machine \#1 } & Exhaust manifold & 2448 & $190.2 \pm 42.3$ & 305.4 & \multirow{4}{*}{42.2} & \multirow{4}{*}{29.9} \\
\hline & SCR & 2448 & $97.3 \pm 19.2$ & 142.1 & & \\
\hline & Gearbox & 2448 & $52.2 \pm 11.3$ & 105.7 & & \\
\hline & Engine transmission output & 2448 & $69.1 \pm 11.4$ & 89.1 & & \\
\hline \multirow{4}{*}{ Machine \#2 } & Particulate filter & 1418 & $109.7 \pm 16.2$ & 154.2 & \multirow{4}{*}{43.8} & \multirow{4}{*}{20.5} \\
\hline & Gearbox & 1418 & $52.5 \pm 9.9$ & 97.1 & & \\
\hline & Engine block & 1418 & $56.2 \pm 5.2$ & 69.2 & & \\
\hline & Engine transmission output & 1418 & $81.1 \pm 8.6$ & 95.1 & & \\
\hline \multirow{3}{*}{ Machine \#3 } & Exhaust manifold & 608 & $118.2 \pm 27.3$ & 159.9 & \multirow{3}{*}{42.6} & \multirow{3}{*}{22.6} \\
\hline & Engine block & 1121 & $77.6 \pm 9.7$ & 87.9 & & \\
\hline & Engine transmission output & 1121 & $69.4 \pm 11.7$ & 87.7 & & \\
\hline \multirow{4}{*}{ Machine \#4 } & Exhaust manifold & 968 & $216.7 \pm 42.5$ & 289.9 & \multirow{4}{*}{44.8} & \multirow{4}{*}{15.8} \\
\hline & Engine block & 968 & $72.5 \pm 6.2$ & 82.3 & & \\
\hline & Engine transmission output & 968 & $55.8 \pm 7.6$ & 70.4 & & \\
\hline & Hydrostatic system output & 968 & $54.9 \pm 7.4$ & 69.5 & & \\
\hline \multirow{4}{*}{ Machine \#5 } & Exhaust manifold & 963 & $155.8 \pm 21.2$ & 222.7 & \multirow{4}{*}{44.9} & \multirow{4}{*}{16.4} \\
\hline & Engine block & 963 & $78.3 \pm 8.5$ & 93.1 & & \\
\hline & Hydrostatic system output & 963 & $51.4 \pm 5.9$ & 67.8 & & \\
\hline & Engine cylinder heads & 963 & $70.2 \pm 4.5$ & 78.8 & & \\
\hline \multirow{3}{*}{ Machine \#6 } & Exhaust manifold & 1665 & $82.5 \pm 13.1$ & 105.8 & \multirow{3}{*}{47.9} & \multirow{3}{*}{11.2} \\
\hline & Engine block & 866 & $70.1 \pm 8.1$ & 85.9 & & \\
\hline & Engine transmission output & 1665 & $60.3 \pm 8.7$ & 80.4 & & \\
\hline \multirow{3}{*}{ Machine \#7 } & Exhaust manifold & 1036 & $110.6 \pm 21.8$ & 156.4 & \multirow{3}{*}{ - } & \multirow{3}{*}{ - } \\
\hline & Engine block & 1036 & $71.4 \pm 7.7$ & 87.7 & & \\
\hline & Engine transmission output & 1036 & $65.2 \pm 9.3$ & 80.1 & & \\
\hline \multirow{3}{*}{ Machine \#8 } & Exhaust manifold & 773 & $163.3 \pm 35.0$ & 230.3 & \multirow{3}{*}{-} & \multirow{3}{*}{ - } \\
\hline & Engine block & 773 & $73.7 \pm 6.2$ & 84.9 & & \\
\hline & Engine transmission output & 773 & $39.6 \pm 12.3$ & 70.6 & & \\
\hline & Exhaust manifold & 574 & $132.8 \pm 46.9$ & 243.2 & & \\
\hline Machine \#9 & Engine block & 574 & $69.3 \pm 4.6$ & 78.8 & 42.8 & 21.2 \\
\hline & Engine transmission output & 574 & $70.8 \pm 10.6$ & 94.2 & & \\
\hline
\end{tabular}

\footnotetext{
$\mathrm{T}_{\mathrm{op}}$ stands for operating temperature (average \pm standard deviation) and $\mathrm{T}_{\max }$ stands for maximum registered
} temperature. SCR stands for selective catalytic reduction.

Figure 5 shows the histogram of the time periods in which the temperature exceeded $250{ }^{\circ} \mathrm{C}$ in machines \#1 and \#4. Although in most of the periods the duration was close to $10 \mathrm{~min}$, a period of 100 consecutive minutes with temperatures above $250{ }^{\circ} \mathrm{C}$ was registered in machine $\# 4$, and a period of $70 \mathrm{~min}$ was recorded for machine \#1. This fact, taking into consideration the ignition times of the crop residue (Table 4), reinforces the conclusion regarding the high fire risk at the exhaust manifold of machines \#1 and \#4. 

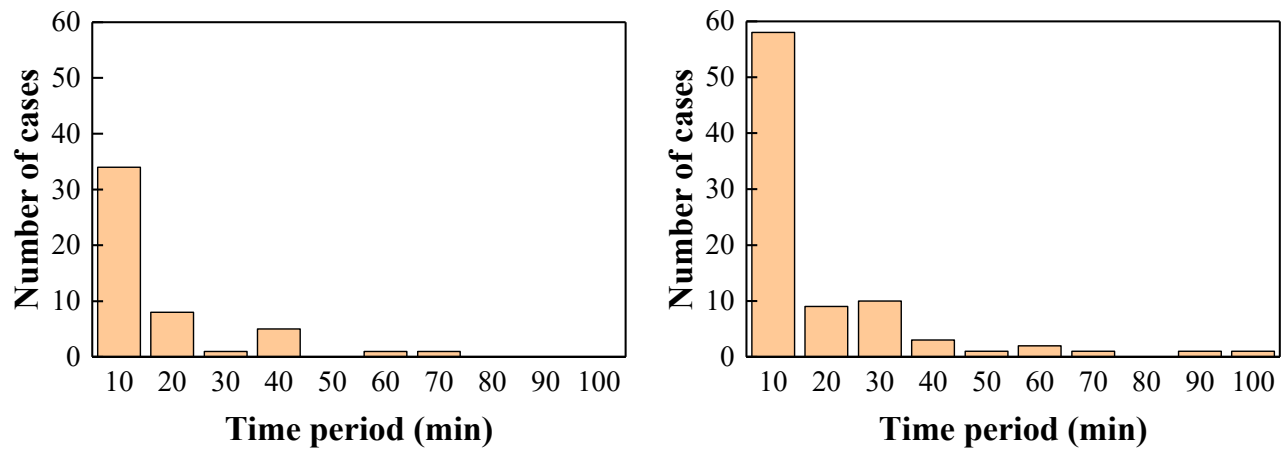

Figure 5. Histogram of time periods in which temperatures above $250{ }^{\circ} \mathrm{C}$ were reached in the exhaust manifold. Left: Machine \#1; Right: Machine \#4.

The tests carried out with the cutting bar, the second most important cause of fire according to data from the survey, made it possible to compare temperature evolution in a blade operating in normal conditions compared to a blade subjected to friction (Figure 6). It was observed that 10-15 min after the movement of the cutting blade had started, the friction blade had reached $428^{\circ} \mathrm{C}$ (compared to a maximum temperature of $52{ }^{\circ} \mathrm{C}$ for a blade that operated in normal conditions). In the thermal image (Figure 6, right), the difference in temperature between the blade subjected to friction and the other blades working in normal conditions becomes apparent. A short video is provided in supporting information (video S1). Poor maintenance, in this case of the cutting bar, can result in abnormal temperatures and frictional spark generation, which in the presence of agricultural waste can easily cause a fire.
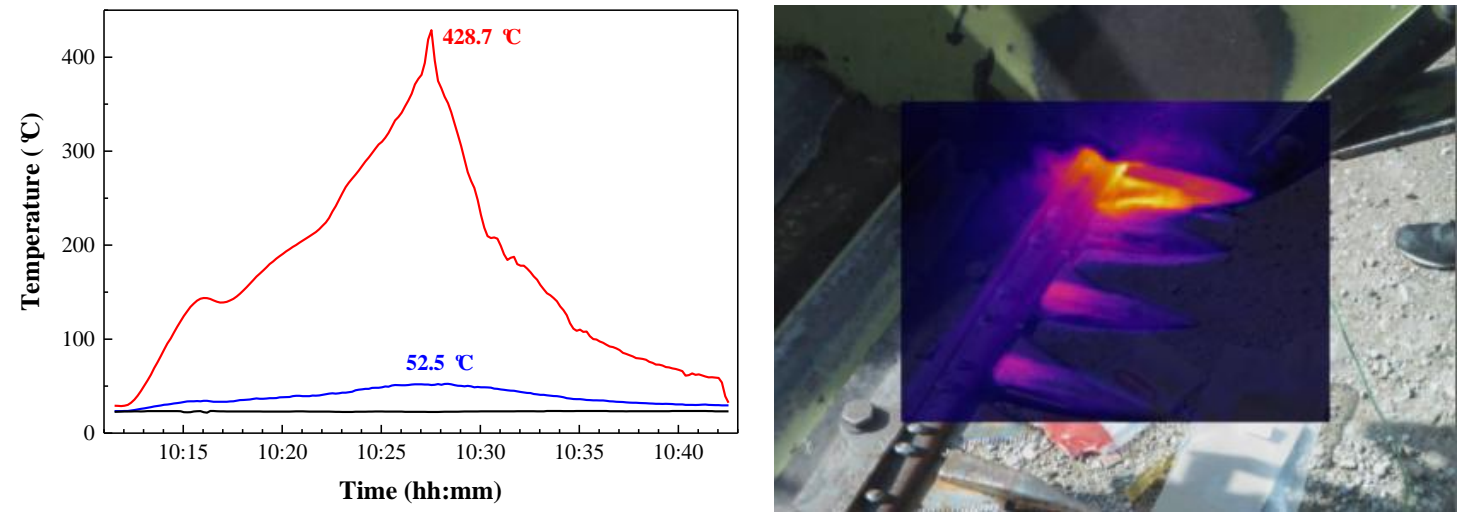

Figure 6. Left: Temperature evolution in the cutting bar for a blade in good conditions (blue) and for a blade subjected to friction (red). The ambient temperature is shown in black. Right: Thermal image of blade subjected to friction.

To the best of the authors' knowledge, this is the first report on the temperature that a cutting bar subjected to friction can reach. In this sense, fire risk related to the cutting bar has generally been associated with the sparks caused by some stones when struck by metallic harvester front components such as the skid plates or even the sickle bar [5].

\section{Conclusions}

From the statistical analysis of the survey data, with regard to the technical characteristics of the harvesters, only the total hectares harvested in the lifetime of the machine had a significant relationship with the fire risk, in such a way that the risk of fire would considerably increase over 6000 accumulated ha. In relation to the areas of highest risk within the harvester, $32 \%$ of the fires had their origin in the area of the engine, compared with $31 \%$ in the cutting bar and $18 \%$ in the bearings and belts. 
From the ignition point experiments conducted using wheat residue samples to describe conditions that could start fires in the harvesters, it was found that ignition temperatures would range from 250 to $340{ }^{\circ} \mathrm{C}$, depending on the size and thickness of the wheat waste, in good agreement with thermal analysis (TG, DTG, DSC) results. In tests carried out in situ on nine harvesters, temperatures of up to $300{ }^{\circ} \mathrm{C}$ were detected in the engine area (exhaust manifold). Significant temperature differences on the exhaust manifold were found depending on the exhaust gases treatment system, with the highest mean temperatures for SCR + EGR and SCR + EGR + DPF systems. In the cutting bar, a blade working in friction conditions reached temperatures above $400{ }^{\circ} \mathrm{C}$. These temperatures, together with the accumulation of crop residue, would be responsible for the origin of the fires. The identification of the points of the machine with the greatest risk of fire opens the way to implement measures to minimize this risk, such as continuous monitoring by means of temperature sensors that provide warnings in the machine cabin, in the same way that remote sensors are currently used to assess the susceptibility of forest masses and crops.

Supplementary Materials: The following are available online at http://www.mdpi.com/2073-4395/9/12/877/s1. Table S1: Proximate analysis and elemental analysis results for the wheat residues; Table S2: Granulometric analysis results for the wheat residues from five combine harvesters used in the hot plate auto-ignition studies; Figure S1: DSC, TG, and DTG curves for wheat residues in inert and oxidative conditions; Table S3: Tests of between-subjects effects (results from univariate analysis) for temperatures as a function of the exhaust gases treatment system.; Figure S2: Results from univariate analysis for temperatures as a function of the exhaust gases treatment system; Video S1: Temperature evolution in a cutting bar.

Author Contributions: Conceptualization, F.J.G.-R.; Methodology, F.J.G.-R., P.M.-R., M.V.-C., and A.B.-G.; Validation, F.J.G.-R. and M.V.-M.; Formal analysis, J.P.V.-A., F.J.G.-R., and P.M.-R.; Investigation, J.P.V.-A., M.-V.-M., F.J.G.-R., P.M.-R., M.V.-C., and A.B.-G.; Resources, F.J.G.-R.; Writing-original draft preparation, J.P.V.-A., F.J.G.-R., and P.M.-R.; Writing—review and editing, F.J.G.-R. and P.M.-R.; Visualization, J.P.V.-A., F.J.G.-R., and P.M.-R.; Supervision, F.J.G.-R. and P.M.-R.; Project administration, F.J.G.-R.; Funding acquisition, F.J.G.-R.

Funding: This research was funded by Gobierno de Aragón, under project "ICO: Análisis de riesgos de incendios en cosechadoras de cereales" (Order DRS/190/2017).

Acknowledgments: The authors would like to acknowledge the use of Servicio General de Apoyo a la Investigación-SAI, Universidad de Zaragoza. The collaboration of ASAJA Huesca, AGPME-Itaga, AGRACON, ANSEMAT, Sociedad Cooperativa del Campo Santa Leticia, JACA-LARRAZ agricultural services, Berdún Canal agricultural services, and COGASAL garage is also gratefully acknowledged.

Conflicts of Interest: The authors declare no conflict of interest.

\section{References}

1. Shah, V.; Twidwell, D.; Wonkka, C.L.; Sindelar, M.T.; Weir, J.R. First Approximations of Prescribed Fire Risks Relative to Other Management Techniques Used on Private Lands. PLoS ONE 2015, 10, e0140410.

2. Vélez, R. El reto de la prevención de los incendios forestales en un ambiente global. In Proceedings of the II Congreso Forestal Español, Dirección General de Conservación de la Naturaleza, Pamplona, Spain, 23-27 June 1997; pp. 479-484.

3. Birot, Y.; Rigolot, E. La necesidad de estrategias que se anticipen al cambio climático entre otros. In Convivir con los Incendios Forestales: Lo que nos Revela la Ciencia; Birot, Y., Ed.; European Forest Institute: Joensuu, Finland, 2009; pp. 82-85.

4. Bragachini, M.A.; Mendez, A.A.; Peiretti, J.; Santa Juliana, D.M.; Velez, J.P.; Sanchez, F.R.; Villarroel, D.D.; Scaramuzza, F.M.; Pognante, J.; Gallarino, A. Incendios de Cosechadoras y Rastrojos en Argentina y su Impacto Económico, Ambiental y Social; INTA: Buenos Aires, Argentina, 2013; p. 15.

5. Quick, G.R. An Investigation into Combine Harvester Fires; Grains Research and Development Corporation: Canberra, Australia, 2010; p. 20.

6. Fernandez-Anez, N.; Garcia-Torrent, J. Influence of particle size and density on the hot surface ignition of solid fuel layers. Fire Technol. 2018, 55, 175-191. [CrossRef]

7. Cardil Forradellas, A.; Salis, M.; Spano, D.; Delogu, G.; Molina Terrén, D. Large wildland fires and extreme temperatures in Sardinia. IForest-Biogeosci. For. 2014, 7, 162-169. [CrossRef] 
8. Shutske, J.; Field, W.E. An Integrated Loss Control Strategy for Grain Combine Fires. In 1988 International Winter Meeting of the American Society of Agricultural Engineers; American Society of Agricultural Engineers: Chicago, IL, USA, 2014; p. 17.

9. Shutske, J.M.; Field, W.E.; Gaultney, L.D.; Parsons, S.D. Agricultural machinery fire losses: A preventative approach. Appl. Eng. Agric. 1990, 6, 575-581. [CrossRef]

10. White, B.; Giumelli, J. RRR-Owner Survey: Harvester Fires; Kondinin Group: Perth, Australia, 2006.

11. Keskin, M.; Şekerli, Y.E. An evaluation of combine harvester accidents in turkey. J. Agric. Fac. Mustafa Kemal Univ. 2018, 23, 137-147.

12. Bagavathiappan, S.; Saravanan, T.; George, N.P.; Philip, J.; Jayakumar, T.; Raj, B. Condition monitoring of exhaust system blowers using infrared thermography. Insight-Non-Destr. Test. Cond. Monit. 2008, 50, 512-515. [CrossRef]

13. Stawicki, T.; Sędłak, P. Thermal imaging studies on grain harvester belt transmissions. Diagnostyka 2015, 16, $36-42$.

14. Polin, J.P.; Gu, Z.; Humburg, D.; Dalsted, K. Sunflower dust properties that contribute to increased fire risk during harvest and biorefinery operations. Ind. Crop. Prod. 2013, 50, 227-231. [CrossRef]

15. Polin, J.P.; Gu, Z.; Humburg, D.S.; Dalsted, K.J. Source of airborne sunflower dust generated during combine harvester operation. Biosyst. Eng. 2014, 126, 23-29. [CrossRef]

16. Venem, M.; Shutske, J. Combine fire prevention and control summit. In Proceedings of the 2002 ASAE Annual Meeting/CIGR XVth World Congress, American Society of Agricultural and Biological Engineers, Chicago, IL, USA, 28-31 July 2002; p. 028017.

17. Cardil, A.; Molina, D.M.; Kobziar, L.N. Extreme temperature days and their potential impacts on southern Europe. Nat. Hazards Earth Syst. Sci. 2014, 14, 3005-3014. [CrossRef]

(C) 2019 by the authors. Licensee MDPI, Basel, Switzerland. This article is an open access article distributed under the terms and conditions of the Creative Commons Attribution (CC BY) license (http://creativecommons.org/licenses/by/4.0/). 